\title{
PERAN DIMENSI MENTORING DALAM UPAYA PENINGKATAN KUALITAS SUMBER DAYA MANUSIA
}

\author{
Nikodemus Thomas Martoredjo \\ Character Building Development Center, BINUS University \\ Jln. Kemanggisan Ilir III No. 45, Kemanggisan-Palmerah, Jakarta Barat 11480 \\ Niko3_075@yahoo.com
}

\begin{abstract}
This article discusses the development of human resources within an organization or company. One approach that can be done to improve the quality of human resources is mentoring activities. By using library study method, research found that mentoring activities give a positive impact not only for the mentee but also for the mentor and can improve performance of the organization or company. Thus mentoring with a variety of models can be used effectively for the development of human resources in order to support the organization to be more competitive and to face the globalization. Although there are challenges in implementing mentoring activities, with good planning and regular evaluation, maximum results can be achieved.
\end{abstract}

Keywords: human resource development, mentoring, mentor, mentee

\begin{abstract}
ABSTRAK
Artikel membahas tentang pengembangan sumber daya manusia dalam suatu organisasi atau perusahaan. Salah satu pendekatan yang dapat dilakukan untuk meningkatkan kualitas sumber daya manusia tersebut adalah dengan kegiatan mentoring. Dengan menggunakan metode riset kepustakaan ditemukan bahwa kegiatan mentoring mempunyai dampak positif tidak hanya terhadap mentee tetapi juga memberi dampak yang baik bagi mentor dan dapat meningkatkan kinerja organisasi atau perusahaan. Dengan demikian, mentoring dengan berbagai modelnya dapat digunakan secara efektif untuk pengembangan sumber daya manusia agar mendukung organisasi untuk lebih kompetitif menghadapi kemajuan dan tuntutan globalisasi. Meskipun ada tantangan dalam menerapkan kegiatan mentoring, dengan perencanaan yang baik serta evaluasi berkala, hasil yang maksimal dapat dicapai.
\end{abstract}

Kata kunci: pengembangan SDM, mentoring, mentor, mentee 


\section{PENDAHULUAN}

Dengan makin berkembangnya dunia bisnis dan industri, perhatian terhadap aspek tenaga kerja atau dimensi manusia sebagai sumber daya menjadi bertambah lebih besar. Manusia sebagai pelaku utama dalam industri tidak lagi dianggap sebagai suatu objek yang dapat diperlakukan sekehendak hati, tetapi sebagai sumber daya yang penting dan bersifat strategis. Sumber daya ini perlu mendapatkan perhatian yang pantas dan sesuai agar potensi yang dimiliki sebagai sumber daya dapat ditingkatkan secara optimal. Pemanfaatan potensi sumber daya manusia memerlukan suatu perencanaan yang baik, pelaksanaan yang konsisten, dan pengendalian yang kontinu, agar tujuan yang diinginkan dapat dicapai secara efisien dan efektif. Oleh karena itu diperlukan adanya sistem pengaturan dan pengendalian sumber daya tersebut yaitu aspek manusia itu sendiri. Pengaturan tersebut akan memberi dampak yang positif bagi perusahaan atau organisasi karena hal tersebut mampu memberdayakan potensi yang ada secara terorganisasi sehingga menghasilkan kinerja yang jauh lebih baik (Mangkunegara, 2004:2).

Di samping hal tersebut, perkembangan di bidang teknologi juga sangat berpengaruh pada aspek sumber daya manusia. Perkembangan teknologi tersebut menyebabkan timbulnya peralatan dan mesin-mesin baru yang lebih canggih dan lebih efisien yang digunakan oleh perusahaan. Sebagai akibatnya, ada beberapa pekerjaan yang hilang dan muncul jenis pekerjaan yang baru. Atau bisa juga terjadi pekerjaan masih tetap sama namun memerlukan tambahan pengetahuan dan keterampilan yang memadai. Para tenaga kerja memerlukan tambahan pengetahuan dan keterampilan yang baru itu.

Perkembangan dunia usaha dan bisnis, perkembangan teknologi dan perkembangan ilmu pengetahuan, serta perkembangan hubungan internasional di bidang sosial, politik, dan ekonomi membawa akibat perlunya peningkatan kualitas sumber daya manusia. Pelatihan dan pengembangan tenaga kerja secara terencana dan berkesinambungan menjadi sesuatu yang mutlak agar perusahaan dan pelaku dalam dunia industri mampu bersaing baik di dalam maupun di luar negeri dan juga mampu untuk terus maju dan berkembang (Greenberg \& Baron, 2003:588).

Salah satu cara untuk mengembangkan sumber daya manusia adalah dengan kegiatan mentoring. Berdasarkan pengalaman, pelatihan formal yang disediakan organisasi biasanya kurang memberi dampak yang cukup baik dalam membekali sumber daya manusia dengan pengetahuan, keterampilan, sikap atau hal lainnya. Karena itu Kaswan (2012:11) menganggap bahwa mentoring dan juga coaching merupakan cara yang sangat efektif membantu mengembangkan sumber daya manusia yang dimiliki organisasi pada zaman milenium ini. Mentoring akan meningkatkan kualitas kinerja dan efektivitas kerja dari anggota organisasi melalui percakapan intensif, pengarahan diri, dan peningkatan kepercayaan diri dalam berkontribusi positif pada organisasi. Tren dalam dunia bisnis yang berkembang saat ini membuat kegiatan mentoring menjadi sesuatu yang tidak hanya sangat diperlukan tetapi menjadi hal yang pokok dalam mencapai kesuksesan bagi organisasi maupun sumber daya manusia yang ada di dalamnya (Janasz et al, 2009:336).

Berkaitan dengan latar belakang tersebut, maka pokok permasalahan yang akan dibahas dalam tulisan ini dirumuskan sebagai berikut. Pertama, apakah peran dimensi mentoring dalam upaya peningkatan dan kualitas sumber daya manusia dalam suatu organisasi. Kedua, bagaimanakah modelmodel mentoring yang dapat diterapkan di dalam organisasi untuk mengembangkan potensi sumber daya manusia.

Penelitian ini diharapkan dapat menelaah hal-hal yang berkaitan dengan peran dimensi mentoring dalam usaha peningkatan sumber daya manusia yang terdapat dalam organisasi serta menemukan model-model mentoring yang dapat diterapkan di dalam organisasi untuk mengembangkan potensi sumber daya manusia. Lebih lanjut tulisan ini dapat memberikan masukan bagi organisasi dalam rangka usaha meningkatkan kualitas sumber daya manusia untuk meningkatkan kinerja organisasi. 


\section{METODE}

Penelitian ini menggunakan riset kepustakaan (library research) sebagai metode penelitian untuk mengembangkan topik yang dibahas. Studi kepustakaan merupakan metode yang dilakukan oleh peneliti untuk menghimpun informasi yang relevan dan berkaitan dengan topik tersebut. Penelitian menggunakan bahan-bahan yang bukan berasal dari sumber pertama sebagai sarana untuk memperoleh data dan informasi. Informasi diperoleh dan dikaji dari buku-buku ilmiah, laporan penelitian, karangan-karangan ilmiah, tesis dan disertasi, peraturan-peraturan, ketetapan-ketetapan, buku tahunan, ensiklopedia, kamus dan sumber-sumber tertulis lainnya baik yang tercetak maupun elektronik (Sarwono, 2006:47).

Dalam melakukan studi pustaka, peneliti berusaha untuk mendapatkan gambaran dan informasi mengenai hal-hal yang berkaitan dengan topik yang dibahas. Dalam studi kepustakaan tersebut dipakai sumber bacaan yang relevan dan tersedia untuk mengembangkan topik. Hasil dari studi kepustakaan tersebut kemudian dituangkan dalam uraian dan ditambahkan refleksi untuk memperdalam materi serta dibuat sebuah simpulan untuk memperkaya materi yang ada.

\section{PEMBAHASAN}

\section{Peran dan Fungsi Manajemen Sumber Daya Manusia}

Sumber daya manusia merupakan aset yang sangat penting dari suatu organisasi. Perannya menjadi sangat vital dan strategis karena keberadaannya tidak bisa tergantikan oleh sumber daya yang lain. Betapapun kemajuan teknologi, atau seberapapun sumber daya dana yang tersedia namun tanpa dukungan sumber daya manusia yang berkualitas dan kompeten, semunya menjadi tidak bermakna.

Kondisi dinamis yang makin mudah berubah menuntut eksistensi dari sumber daya manusia agar mampu beradaptasi dengan keadaan tersebut. Sumber daya manusia dalam organisasi harus terus berorientasi pada tujuan perusahaan atau organisasi. Dinamika organisasi berjalan terus mengikuti dinamika perubahan. Keberhasilan organisasi merealisasikan visi dan misinya akan sangat tergantung dari kemampuan sumber daya manusianya yang didukung oleh sumber daya yang lainnya.

Strategi dalam mengoptimalkan sumber daya manusia merupakan seperangkat proses dan aktivitas yang dilakukan untuk menyelesaikan masalah organisasional yang terkait dengan manusia (Mangkunegara, 2004:1). Hal ini berhubungan dengan iklim dan budaya organisasi yang terdapat di lingkungan kerja dan stakehorlder. Strategi yang efektif harus didukung oleh struktur dan budaya kerja yang jelas. Implementasi strategi yang didukung oleh kebijakan yang mengatur mekanisme kerja dapat menciptakan budaya kerja profesional dalam upaya mencapai tujuan organisasi.

Peran manajemen sumber daya manusia dalam perkembangannya mengalami pergeseran, dari yang bersifat konvensional menjadi suatu paradigma baru. Paradigma lama cenderung bersifat tradisional, yaitu perannya berfokus pada urusan administrasi kepegawaian seperti rekrutmen, seleksi, pemeliharaan dan pengembangan, penilaian sampai pemutusan kerja. Sementara paradigma baru manajemen sumber daya manusia memiliki peran strategis dalam organisasi yaitu untuk memperoleh dan mempertahankan keunggulan kompetitif organisasi melalui kegiatan-kegiatan seperti pengawasan anggaran, peningkatan dan pengembangan daya saing secara komparatif, optimalisasi sumber daya organisasi dan pendekatan manajemen proaktif untuk meningkatkan kreativitas dan fleksibilitas organisasi (Sastradipoera, 2006:4). 
Sementara itu salah satu aspek penting yang akan menentukan keberhasilan ataupun kegagalan suatu organisasi dapat dilihat dari implementasi manajemen sumber daya manusianya. Yuniarsih dan Suwatno (2008:84) menyebutkan secara garis besar fungsi manajemen sumber daya manusia dibagi menjadi dua dimensi, yaitu fungsi manajerial dan fungsi operatif. Dari fungsi manajerial sekurangkurangnya ada lima fungsi esensial yaitu perencanaan (planning), staffing, pengarahan (directing), pembinaan (supervising), dan pengendalian (controlling). Di sisi lain fungsi operatif dari manajemen sumber daya manusia adalah pengadaan (procurement), pengembangan (development), kompensasi (compensation), integrasi (integration), pemeliharaan (maintenance) dan pemutusan hubungan kerja (separation).

Keberhasilan dalam implementasi fungsi-fungsi operatif lewat sentuhan manusiawi (human touch) dalam praktik manajerial dari pimpinan oraganisasi akan memberikan dampak positif bagi organisasi. Dalam menghadapi tuntutan global dengan segala tantangannya, organisasi sangat membutuhkan sumber daya manusia yang mampu menampilkan keunggulannya dengan optimalisasi potensinya yaitu intellectual capital yang didukung oleh informasi berbasis teknologi dan kemampuan beradaptasi menghadapi perubahan. Hal ini merupakan tantangan baru bagi organisasi untuk membangun human capital dan menjalankan knowledge management.

\section{Pengembangan Sumber Daya Manusia}

Pengembangan (development) merupakan bagian dari fungsi operasional manajemen sumber daya manusia. Pengembangan dari sumber daya manusia yang tersedia baik yang sudah lama maupun yang masih baru perlu dilakukan secara berkesinambungan untuk mencapai tujuan dari organisasi dan siap untuk bersaing dalam kompetisi.

Berdasarkan pandangan Hasibuan (2003:68) pengembangan sumber daya manusia merupakan suatu usaha untuk meningkatkan kemampuan teknis, teoretis, konseptual, dan moral sumber daya manusia sesuai dengan kebutuhan pekerjaan/jabatannya melalui pendidikan dan pelatihan. Pendidikan dapat meningkatkan keahlian teoretis, konseptual, dan moral para pekerja sementara pelatihan bertujuan untuk meningkatkan keterampilan teknis pelaksanaan tugas pekerja. Dengan pengembangan sumber daya manusia ini, melalui pendidikan dan pelatihan, bukan hanya akan memberi manfaat bagi organisasi tetapi juga bagi orang itu sendiri, dan tentu juga akan memberi dampak bagi masyarakat selaku konsumen.

Sumber daya manusia yang berkualitas tinggi merupakan aset yang sangat berguna bagi organisasi. Akan tetapi, dengan perkembangan masa dan juga pertumbuhan organisasi yang dinamis potensi yang ada harus terus diasah dan ditingkatkan agar dapat mengikuti tuntutan dinamika lingkungan. Organisasi yang baik dan maju akan selalu peduli terhadap pengembangan potensi sumber daya manusianya. Pengembangan karyawan merupakan kunci bagi strategi bisnis yang didasarkan pada pengembangan modal intelektual, mengembangkan talenta manajerial, dan memberi kesempatan bagi anggota organisasi untuk bertanggung jawab atas kariernya sendiri. Di sisi lain, pengembangan ini juga merupakan komponen penting dalam suasana iklim ekonomi yang penuh persaingan untuk menjawab tantangan global dan perubahan sosial serta untuk memadukan antara kemajuan dan perubahan teknologi dalam desain pekerjaan.

Aktivitas pengembangan sumber daya manusia dalam organisasi ini juga dapat menjadi jalan untuk mempertahankan tenaga potensial dengan cara mengembangkan ketrampilan manajerial. Dalam hal ini organisasi atau perusahaan mendorong pimpinannya agar dapat mengembangankan keterampilan dalam komunikasi, menciptakan kepercayaan dan melakukan pembinaan serta hubungan antarpribadi dalam organisasi. Menurut Noe (Kaswan, 2012:3) ada empat pendekatan dalam mengembangkan sumber daya manusia dalam organisasi atau perusahaan, yaitu pendidikan formal, penilaian, pengalaman kerja dan hubungan interpersonal. Dalam pendekatan interpersonal tersebut terdapat metode coaching dan mentoring antara pihak-pihak yang terkait di dalamnya. Di sini personal 
dapat meningkatkan ketrampilan sekaligus menambah pengetahuannya tentang pekerjaan dan organisasi maupun aspek lainnya melalui interaksi dengan personal lain yang lebih berpengalaman dan lebih ahli.

\section{Dimensi Mentoring dalam Pengembangan SDM}

\section{Ruang Lingkup dan Manfaat Mentoring}

Mendapatkan orang-orang bertalenta sebagai suatu proses awal manajemen sumber daya manusia dalam suatu organisasi merupakan langkah awal yang sangat penting. Kehadiran orang-orang yang dapat diandalkan dapat menunjang tercapainya tujuan dari organisasi. Akan tetapi, hal tersebut tidak menjamin sepenuhnya apabila tidak didukung dengan pengembangan sumber daya manusia yang ada dengan optimal. Kemajuan dan pertumbuhan organisasi serta kondisi dinamis dari lingkungan organisasi menuntut adanya penyesuaian yang pantas. Oleh karena itu, pengembangan sumber daya manusia menjadi kunci dari usaha organisasi untuk siap bersaing dan mengikuti tuntutan yang ada.

Mentoring sabagai salah satu pendekatan dalam pengembangan sumber daya manusia menjadi bagian penting untuk menciptakan organisasi yang siap bersaing dalam kemajuan dan persaingan usaha. Kaswan (2012:13) menjelaskan mentoring sebagai sebuah kemitraan antara mentor (yang memberi bimbingan) dan mentee (yang menerima bimbingan). Mentoring merupakan suatu hubungan interpersonal dalam bentuk kepedulian dan dukungan antara seorang yang berpengalaman dan berpengetahuan luas dengan seorang yang kurang berpengalaman ataupun yang pengetahuannya masih sedikit.

Jadi dalam mentoring tercermin hubungan yang unik antarpribadi. Tidak ada hubungan mentoring yang sama karena terjadi interaksi khusus yang berbeda satu sama lainnya. Dalam hubungan yang unik tersebut terjadi kemitraan pembelajaran. Hampir semua hubungan mentoring melibatkan penguasaan pengetahuan namun perlu juga ditekankan bahwa mentoring ini meski bersifat timbal balik meskipun pada dasarnya tidak seimbang. Mentor dapat saja mendapatkan keuntungan dari kegiatan tersebut namun sasaran utamanya adalah pertumbuhan dan perkembangan mentee.

Kegiatan mentoring merupakan aktivitas yang sangat menekankan pada relasi antara pihakpihak terkait. Meskipun demikian, relasi yang ada merupakan hubungan yang sangat spesifik, yaitu ruang lingkup utama mentoring berupa prestasi/kinerja dan sumber bantuan. Bagaimanapun, hasrat untuk berprestasi atau memiliki kinerja optimal merupakan hal yang sangat penting dalam segala bidang. Di dalam pekerjaan, khususnya di awal pekerjaan, amat penting untuk mengetahui seluk beluk pekerjaan dan organisasi untuk mengembangkan dengan cepat kompetensi agar sukses di tempat kerja. Pada masalah inilah mentoring menjadi sumber informasi dan bantuan yang sangat berharga untuk menggapai kinerja yang optimal dalam waktu yang relatif singkat.

Banyaknya sarana bantuan yang tersedia bertujuan untuk membantu seseorang menjadi mahir dan dapat mencapai tujuan pribadi dan sasaran yang dituju organisasi. Akan tetapi, sumber bantuan itu sering memiliki unsur-unsur yang sama yaitu diberikan secara formal dan dilaksanakan dalam manajemen lini. Oleh karena itu timbul kesulitan sebagai individu untuk mengungkapkan masalahmasalah pribadi dan niat pengembangan diri yang sebenarnya. Dalam permasalahan inilah mentoring menjadi bantuan yang sangat bernilai untuk mendapatkan bantuan dan dukungan yang diharapkan.

Adanya kegiatan mentoring seperti ini akan sangat membantu, tidak hanya orang-orang yang terlibat dalam kegiatan tersebut tersebut, tetapi juga kepada organisasi dan masyarakat pada umumnya. Mentoring menjadi sarana yang menarik untuk pengembangan sumber daya manusia. Mentoring mampu untuk meningkatkan kinerja sumber daya manusia dalam perusahaan (Turner, 2012:17). Di dalam mentoring ini ada hubungan komunikasi yang baik kepada pihak atasan; dan sebaliknya, pihak atasan dapat memantau dan mengarahkan bawahannya. Jika ini berjalan dengan baik, sumber daya 
manusia yang masih kurang berpengalaman atau kurang mahir cenderung akan belajar dengan cepat dan sebagai dampaknya dapat menjadi lebih produktif. Mentor dapat menjadi model perilaku yang sesuai dan memberi umpan balik yang spesifik serta mengidentifikasi praktik-praktik terbaik.

Selain makin memberdayakan (empowerment) sumber daya manusia yang ada, mentoring juga dapat memberi dampak motivasi bagi para pelakunya. Mentoring dapat menjadi langkah pengembangan diri dan karier (Ivancevich \& Hoon, 2002:198). Sering terjadi semangat ambisi dari orang muda menjadi tersendat karena frustasi dan ketidaksabaran setelah menyadari bahwa kemajuan yang dialaminya berjalan sangat lambat daripada yang diharapkan. Akan tetapi jika mereka memiliki mentor yang menaruh perhatian dan minat pada perkembangan karier mereka, mereka akan menjadi antusias dan bisa bertahan. Ditambah lagi, harapan akan keberhasilan dan hubungan sosial di dalam organisasi akan makin meningkat. Sementara itu mentor juga mendapatkan motivasi dan terhindari dari kejenuhan. Mereka akan dihadapkan pada situasi ketika mereka harus mengartikulasikan secara jelas ide dan tujuan organisasi dengan baik. Mereka juga didorong untuk meningkatkan kemampuan diri agar dapat menjadi mentor yang baik. Hal ini tentu akan sangat baik bagi organisasi, selain dapat meningkatkan produktivitas, situasi ini juga dapat mencegah terjadinya turnover dan masalah-masalah lain yang berhubungan dengan ketenagakerjaan, yang berimplikasi biaya besar.

\section{Model-model Mentoring}

Memasuki era kemajuan teknologi yang sangat cepat dibutuhkan daya adaptasi yang baik untuk dapat memenuhi tuntutan dari kemajuan tersebut. Manajemen sumber daya manusia harus siap untuk mengantisipasi keadaan tersebut. Dalam hal ini mentoring dapat menjadi pendukung sistem pendidikan formal bagi sumber daya manusia dalam membantu mengembangkan dan memperkuat pembelajaran mandiri (self directed learning), membangun rasa percaya diri, meningkatkan loyalitas bagi organisasi, membangun karier, meningkatkan potensi dan produktivitas yang pada akhirnya memberi efek positif bagi organisasi.

Mentoring menjadi sarana yang efektif untuk membangun dan meningkatkan produktivitas sumber daya manusia karena mentoring menjadikan proses pembelajaran menjadi lebih cepat. Mentor dapat menjadi model, memberi umpan balik dengan cepat, dan mengindentifikasikan praktik-praktik yang baik. Di sisi lain, kompetensi substansial dari mentee dapat berkembang dengan optimal karena mentoring membantu sumber daya manusia yang ada untuk menguasai pengetahuan, keterampilan, dan sikap yang berhubungan langsung dengan pekerjaan mereka. Hubungan interpersonal juga tercipta dengan baik karena adanya interaksi yang bernilai positif.

Berdasarkan peran penting mentoring dalam mengembangkan sumber daya manusia, maka kegiatan ini juga diperluas menjadi berbagai variasi model. Didorong oleh kemajuan teknologi yang telah mempersempit ruang dan waktu, maka muncullah model-model mentoring jarak jauh, lintas budaya, kelompok, sesama dan organisasi. Mentoring jarak jauh menggunakan teknologi sebagai media seperti Internet, email, dan sebagainya. Hal ini akan sangat menarik karena dapat menjangkau tempat-tempat yang sulit dan praktis dari segi waktu. Meskipun begitu, model ini membutuhkan prasarana yang cukup memadai dan keterampilan khusus dalam menggunakan media teknologi. Selain itu, model ini kurang bersifat spontan dan hubungan interpersonal yang dibangun kurang efektif.

Model lainnya adalah mentoring lintas budaya. Model ini secara luas dimaksudkan sebagai kemitraan yang melibatkan perbedaan gender, usia, ras/etnik, ataupun kebangsaan. Mentoring lintas budaya terasa makin dibutuhkan mengingat lingkungan kerja makin beragam dalam hal gender, usia, etnik atau kebangsaan. Setiap orang harus dapat bekerja dengan lingkungan yang berbeda dengannya. Menyiapkan pasangan dalam hubungan lintas budaya yang berhasil menjadi tantangan bagi pelaksanaan mentoring yang baik. 
Dalam situasi suatu organisasi memiliki lebih banyak mentee daripada mentor atau ada ketertarikan mengawali proses mentoring dalam skala yang lebih besar, maka mentoring kelompok dapat menjadi alternatif. Ada dua pendekatan mentoring kelompok dalam mencapai tujuan pembelajaran para anggota, yaitu action-learning dan komunitas praktik. Dalam action-learning, dibentuk kelompok yang melakukan pembelajaran secara bersama dalam mengatasi kesulitan dan mencari pemecahan masalah dengan cara bertemu bersama untuk membahas kesulitan-kesulitan yang dialami, bereksperimen, dan berefleksi. Kegiatan ini dilengkapi fasilitator yang kompeten untuk membantu memecahkan masalah. Sementara itu komunitas praktik dimaksudkan sebagai sekelompok orang yang ingin mempelajari sesuatu berkolaborasi dengan suatu kelompok baik secara real maupun virtual. Orang-orang ini memiliki tujuan atau minat yang sama dan belajar satu sama lain dengan berbagi pengalaman dan informasi.

Model mentoring lainnya adalah mentoring sesama. Yang dimaksud dengan mentoring sesama adalah posisi atau kedudukan mentor dan mentee berada pada level yang sama atau kurang lebih sama. Kesulitan mendapatkan mentor yang lebih berpengalaman, kendala waktu, demografi, serta banyaknya turnover menjadikan mentoring sesama diperlukan sebagai alternatif. Mentoring sesama ini terjadi ketika individu pada tingkat tanggung jawab yang sama dengan kemitraannya ingin meningkatkan efektivitas satu sama lainnya. Meskipun efektif dalam jangka pendek, mentoring sesama ini kurang efektif dalam jangka panjang. Mentoring sesama ini dapat berbalik menjadi konflik apabila organisasi berubah menjadi makin berkembang.

Yang terakhir adalah model mentoring organisasi. Dalam mentoring organisasi terjadi hubungan antara bisnis ke bisnis, misalnya dalam kasus lingkungan. Mentoring lingkungan menjadi pendekatan untuk pengalihan pengetahuan manajemen lingkungan. Mentoring lingkungan mempunyai fokus pada penanaman kinerja lingkungan yang makin baik melalui interaksi antara sesama pelaku bisnis. Aneka model mentoring ini telah berkembang sebagai respons terhadap beragam kebutuhan yang muncul dalam organisasi.

\section{Tantangan dalam Mentoring}

Di samping sisi positif, sebagai suatu bentuk hubungan interpersonal, mentoring juga memiliki aspek disfungsional. Aspek itu dapat dialami oleh semua pihak, baik itu mentor, mentee, maupun organisasi. Bahkan dapat terjadi mentoring yang efektif dan sehat pun mungkin ditandai dengan pengalaman negatif dari hal yang relatif kecil sampai hal yang besar (Gravells, 2006:18).

Hubungan dalam mentoring harus menjadi perhatian dalam membangun dan memelihara hubungan antara pihak-pihak yang terkait. Harus disadari bahwa hubungan dalam mentoring tidak selamanya dapat berjalan sesuai dengan yang diharapkan. Jika hal ini sampai terjadi, misalnya terjadi hubungan yang tidak produktif, organisasi dan individu penting untuk meninjau kembali kegiatan mentoring tersebut.

Di sisi lain hal yang mungkin terjadi dalam mentoring adalah bahwa mentor tidak memiliki waktu yang cukup untuk menjalankan tugas dan tanggung jawabnya. Meskipun mentor memiliki niat untuk menolong dan mendukung mentee, tetapi karena keterbatasan waktu, mentoring tidak berjalan dengan baik. Program mentoring yang formal biasanya membutuhkan waktu khusus, sehingga mentor dan mentee perlu mengaturnya dengan baik.

Tantangan lain yang perlu diantisipasi adalah terjadinya perbedaan tujuan, persepsi, dan personalitas antara mentor dan mentee. Ini dapat terjadi jika mentor dipilih berdasarkan posisinya dalam organisasi. Ketika ini terjadi, maka bisa terjadi kekurangan dalam keterampilan khusus yang diharapkan oleh mentee. Ataupun sebaliknya, mentee merasa kurang percaya diri dan menganggap dapat menyia-nyiakan waktu dari mentor-nya. Di sini juga dituntut keteladanan dari mentor seperti tidak memperlihatkan budaya kerja yang negatif dan kebiasan buruk yang dapat ditiru oleh mentee. 
Bagaimanapun, jika dijalankan dengan baik, mentoring akan dapat memberi banyak manfaat bagi organisasi dan individu yang ada di dalamnya. Untuk dapat mengantisipasi berbagai tantangan dalam melaksanakan mentoring, evaluasi terhadap kegiatan tersebut juga diperlukan. Salah satu tujuan diadakannya evaluasi adalah untuk melihat apakah program mentoring mencapai tujuan yang diinginkan (Blanchard \& Thacker, 2010:242). Oleh karena itu, persyaratan yang harus dimiliki dalam program pengembangan sumber daya manusia perlu diperhatikan, termasuk bagi program mentoring.

Persyaratan itu adalah mendasarkan program pengembangan individu pada kebutuhan yang nyata. Artinya, program itu dibuat untuk memenuhi kebutuhan dari para peserta. Jika tanpa dasar yang cukup, program tersebut akan menjadi formalitas saja. Kemudian, tujuan perlu ditetapkan juga. Kebutuhan dari peserta program pengembangan ini dapat diterapkan dalam tujuan yang ingin dicapai. Selain itu, program dengan waktu yang tepat dan tempat yang sesuai dengan fasilitas yang memadai sehingga dapat mendukung program tanpa mengabaikan kewajiban utama perlu dirancang.

Yang perlu juga diperhatikan juga adalah pemilihan mentor yang tepat. Mentor dapat dipilih dari dalam maupun dari luar organisasi, asal kualifikasi yang dimiliki dapat menjawab kebutuhan peserta program mentoring. Untuk menyakinkan bahwa tujuan tercapai, maka perlu diadakan evaluasi secara berkala untuk mengantisipasi kesulitan dan hambatan yang ada dan mencari solusi yang tepat. Dengan demikian, mentoring menjadi kegiatan yang dapat dinikmati dan dijalankan dengan baik sehingga bisa memberikan hasil yang maksimal. Mentor dan mentee mendapatkan hasil yang maksimal sementara organisasi dapat berkembang dan siap untuk menghadapi segala perubahan dan tantangan.

\section{SIMPULAN}

Pengembangan kualitas sumber daya manusia yang dimiliki oleh organisasi atau perusahaan merupakan salah satu langkah strategis untuk mengikuti perkembangan organisasi atau perusahaan dan menghadapi kemajuan teknologi dan persaingan global. Sumber daya manusia yang berkualitas akan memberi kontribusi positif bagi kinerja organisasi atau perusahaan. Salah satu pendekatan yang dapat digunakan untuk mengembangkan sumber daya manusia dari organisasi atau perusahaan adalah dengan kegiatan mentoring.

Mentoring merupakan suatu kegiatan yang melibatkan mentor, yaitu orang yang lebih berpengalaman atau ahli, dan mentee sebagai individu yang mendapat pendampingan. Adanya kegiatan mentoring dapat dengan efektif dan efisien mempersiapkan sumber daya manusia yang kompetetitif. Tantangan kemajuan teknologi dan perubahan yang sangat cepat menuntut organisasi atau perusahaan bergerak dengan cepat.

Bagi mentee, dengan adanya mentoring ini akan sangat membantu karena dapat mempercepat pembelajaran yang mereka lakukan. Mentor dapat langsung menjadi model perilaku dan langsung memberi umpan balik yang spesifik. Di sisi lain mentoring ini memberi motivasi dan peningkatan kualitas kinerja mereka. Mereka merasa mendapatkan contoh dan tempat untuk berkomunikasi langsung mengenai tugas-tugas mereka. Dengan demikian unjuk kerja yang dihasilkan dapat menjadi lebih baik.

Bagi mentor, kegiatan ini dapat memberi kesempatan untuk mengembangkan diri juga. Mentor tidak hanya memberi bimbingan tetapi juga sekaligus belajar dan mengembangkan diri dan kepemimpinan. Kemampuan mereka menjadi makin terasah. Hal ini tentunya dapat meningkatkan penghargaan terhadap diri dan mempertajam kemampuan. Pada akhirnya kegiatan mentoring yang berhasil dengan baik akan memberikan pengaruh yang positif bagi peningkatan kinerja perusahaan. 
Meskipun demikian, juga patut untuk digarisbawahi beberapa tantangan dalam kegiatan mentoring. Kegiatan mentoring sebagai akvititas hubungan antarpersonal membutuhkan keterampilan interpersonal yang memadai. Jika hal ini kurang terpenuhi, kegiatan mentoring akan menjadi formalitas saja yang justru akan berpengaruh pada hubungan sosial yang kurang baik. Selain itu alokasi waktu yang baik diperlukan, sehingga tidak mengganggu tugas utama. Karena itu, diperlukan program dan pedoman yang terencana sehingga semua dapat berjalan baik serta evaluasi secara berkala untuk meninjau pencapaian target yang telah ditentukan.

Dengan demikian jika dipahami konsepnya dengan baik dan diimplementasi dengan benar, kegiatan mentoring menjadi pendekatan yang cukup baik dalam mengembangkan sumber daya manusia dalam organisasi atau perusahaan dan akan memberikan dampak yang positif baginya.

\section{DAFTAR PUSTAKA}

Blanchard, N., \& Thacker, J. (2010). Effective Training, Systems, Strategies and Practices. New Jersey: Prentice Hall.

Gravells, J. (2006). Mentoring start-up entrepreneurs in the East Midlands-troubleshooters and trusted triends. The International Journal of Mentoring and Coaching, 4(2), 3-23.

Greenberg, J., \& Baron, R. (2003). Behavior in Organizations, Understanding and Managing the Human Side of Work. New Jersey: Pearson Education.

Hasibuan, M. (2003). Manajemen Sumber Daya Manusia. Jakarta: Bumi Aksara.

Ivancevich, J. M., \& Hoon, L. S. (2002). Human Resource Management in Asia. Singapore: McGrawHill Education.

Janasz, S. C. De., Dowd, K. O., \& Schneider, B. Z. (2009). Interpersonal Skills in Organizations. Boston: McGraw Hill.

Kaswan. (2012). Coaching dan Mentoring, Untuk Pengembangan SDM dan Peningkatan Kinerja Organisasi. Bandung: Alfabeta.

Mangkunegara, A. (2004). Manajemen Sumber Daya Manusia Perusahaan. Bandung: Remaja Rosdakarya.

Sastradipoera, K. (2006). Pengembangan dan Pelatihan: Suatu Pendekatan Menejemen Sumber Daya Manusia. Bandung: Kappa-Sigma.

Sarwono, J. (2006). Metode Penelitian Kuantitatif dan Kualitatif. Yogyakarta: Graha Ilmu.

Turner, P. S. (2012). A strategic approach to coaching in organisations: A case study. The International Journal of Mentoring and Coaching, 10(1), 9-26.

Yuniarsih, T., \& Suwatno. (2008) Manajemen Sumber Daya Manusia, Teori, Aplikasi dan Isu Penelitian. Bandung: Alfabeta. 